\title{
Transformative-Participatory Legal Research Method for Harmonizing the Existence of the Living Law in Indonesia
}

\author{
Yoefanca Halim, Fricky Sudewo, Jestin Justian \\ Faculty of Law, University of Tarumanagara, Indonesia. Email: yoefancahalim.9a35@gmail.com \\ Faculty of Law, University of Tarumanagara, Indonesia. Email: frickyguardian@rocketmail.com \\ Faculty of Law, University of Tarumanagara, Indonesia. Email: jestinjustian@gmail.com
}

\section{ARTICLE INFO}

Keywords:

harmonizing; legal

research method;

transformative-

participatory research.

How to cite:

Halim, Y., et. al. (2019).

Transformative-

Participatory Legal

Research Method for

Harmonizing the

Existence of the Living

Law in Indonesia. MEDIA

HUKUM, +62 274

387656 (Ext. 220)

\section{Article History:}

Received: 07-09-2019

Reviewed: 19-09-2019

Revised: 21-12-2019

Accepted: 23-12-2019

\begin{abstract}
The most common research which conducted in Indonesia is a doctrinal research, based on the deductive approach. Theoretically, all provisions have noble goals, but in practice there are several difficulties in term of implementation, especially related to existence of living law. Therefore, appropriate legal-research method is needed to counter the polemic, namely the use of transformativeparticipatory legal research method. The article aims to explore how to harmonize the living law with transformative-participatory legal research methods. The method uses in the study is the normative legal research method. The research found that through the transformative-participatory legal research, legal researchers would still accommodate the essence of legal analysis founded in conventional methods, but it will not be confined by those methods. The living law is the essence in society and based on transformative-participatory research method, the law-making process needs a community participation and empowerment.
\end{abstract}

DOI: 10.18196/jmh.20190130

Copyright $\odot 2019$ MEDIA HUKUM. All rights reserved.

\section{Introduction}

The research method is a set of formal sequence that has a standard and level of complexity when the researcher will conduct a study of issues or legal problems to acquire an answer. The purpose of research methods is so that research can be accounted for. The word method itself comes from the word "methodos" which means a method or an orderly way to achieve a desired goal. ${ }^{1}$ When discussing research methods, the topic itself cannot be separated from the word "research". Research is a

\footnotetext{
1 Susanto, A.F. \& Gialdah, T. B. (2016). “Transformative Participatory Legal Research: An Idea and Early
} Concept". Jurnal Litigasi, 17 (2): 3316. 
search effort, meaning that the search for the right knowledge to answer and solve problems faced by humans in their lives. One example is the legal research method, which seeks to find truth based on legal logic of the normative side.

Legal research methods in Indonesia are generally doctrinal divided into dogmatic and empirical legal research methods. These two methods are most often used in conducting research. Both ways, which are generally used, serve as reference in the development of positive law. However, over time legal research began to enter a new phase using mixed methods and could be labeled "socio-legal". Studies in socio-legal usually refer to all parts of the social sciences that give attention to law, the legal process or the legal system. ${ }^{2}$ The method tries to produce new methods that come from combining legal methods with social science. With existing legal research methods that tend to neglect aspects of values and morality and affect the reality of the Living Law that brings result to its abandonment, elimination, and disregard as references in building positive law, a new perspective and methodology are required to solve these problems. The combination of research methods in modern times is trying to be integrated and is hoped to bring a comprehensive paradigm in legal research. While still giving attention to the positive law, The Living Law must also be incorporated so that structures of law could achieve harmony between the decisions of technocrats and will of the people. A "transformative-participatory" form of legal research method is needed to bring a more "grounded" research that fully understands the role of every entity in researching, and no other research could be more relevant than the Transformative-Participatory Legal Research.

The transformative-participatory legal research is legal research which creates more collaborative research for parties and shifts the placing of its object to be its direct subject in the study. It is a legal research method that has a more "grounded" approach and does not confine itself with the normative and empirical facts that current conventional legal research method upholds. It aims to emancipate and transform, or in this journal's context, to harmonize the positive law with the foundational norms founded in society. It is, therefore, the existence of the Living Law in the formation of positive law has a concise position. As stated by Cicero, "ubi societas ibi ius", or if it were to be translated, "where there is a community, there is a law". This expression is in line with Eugene Ehrlich who is a figure in the school of sociological jurisprudence who talks about the Living Law or the law that lives in society. According to Ehrlich, for positive law that to be proper and effective, it must be in accordance with the Living Law that reflects the values that live in its society. ${ }^{3}$ Indonesia, as a country that adopts a "civil law" system, has concern about the provisions of the legislation (existing law). It is because one of the characteristics of civil law is that the codified legislation is to be treated as the primary source of law. 4 However, Indonesia also still recognizes the Living Law as one of its legal sources. It can be seen in the following provisions: ${ }^{5}$

a. Article 18 B Paragraph (2) of the 1945 Constitution of the Republic of Indonesia: A recognition of indigenous peoples and their rights. These provisions indirectly

\footnotetext{
2 Susanto, A.F. (2015). Transformative-Participatory Legal Research. Malang: Setara Press, p. 172.

${ }^{3}$ Kusumaatmadja, M. (2000). Legal Concepts in National Development. Bandung: Penerbit Alumni, p. 13-14.

4 Dainow, J. (1967). "The Civil Law and The Common Law: Some Points of Comparation". The American Journal of Comparative Law, 15 (3): 424.

${ }^{5}$ Hadi, S. Op.Cit., p. 264-265.
} 
recognize and respect the existence of the Living Law in the country and state life. It is indicated by the recognition of villages and customary villages along with their rights sourced from the respective Living Laws;

b. Article 5 of the Judicial Power Act: Requires a judge to explore the sense of law that grows and develops in society. It means that judges in deciding cases are not limited to be the speaker of the law as in the civil law tradition. Judges have the freedom to explore the Living Law for the creation of justice. Even in case of a legal vacuum, legal finding can be used by judges to answer the unprecedented cases based on values and principles that grow and develop in society;

c. In Law Number 5 of 1960 concerning Basic Agrarian Principles: Determine that national land law is based on customary law. The sudden recognition of customary rights indicates it;

d. In Law Number 1 of 1974 concerning Marriage: Determining marriage is legal if it was to be carried out in accordance with their respective religions and beliefs;

e. In the inheritance legal system, it permits pluralistic legal system, where there are Islamic, customary, and western inheritance laws;

There is an acknowledgment of law that lives outside of written norms where customary law and even local wisdom become guidelines that govern human behavior, and customary law and local wisdom should act as components and joints of the national law development. ${ }^{6}$ A law that has long lived in society is not always a written rule but was born from the social relations of people who materially, continuously practice it to a point where they obey it not because of coercive force from those who are in power but based on moral duty. ${ }^{7}$ With a confining focus solely on the statutory law, it neglects aspects of values, morality, and the lack of direct action in conducting research is a common thing. It causes damage to the legal order and the marginalization of small communities because formal policies favor those who are in power. On one hand, statutory law stems from values that develop in society and become what is referred to as law. That is because, sociologically, law is a reflection of the values that are believed by the community as an institution in personal, community, national and state life. ${ }^{8}$

With all that is said, the article will not put its writings mainly on the harmonization between the statutory law and the Living Law as it is not a novelty, but instead aims to criticize current legal research methods that hinder harmonization and then focuses on the transformative-participatory legal research as a relatively new research method in Indonesia and its role as instrument of harmonization. Therefore, based on the background aforementioned above, the issue raised in this article is: "How the transformative-participatory legal research method can harmonize the existence of the Living Law in Indonesia?"

\footnotetext{
6 Prabandani, H.W. (2011). "Local Wisdom-Based Legal Development". Jurnal Perencanaan Pembangunan, 17 (1): 32.

7 Hadi, S. (2017). "Positive Law and the Living Law (Its Existence and Enforceability in Society)". Dih Jurnal Hukum, 13 (26): 260.

8 Hoesein, Z.A. (2012). "Legal Formation in the Perspective of the Legal Reform". Jurnal Rechts Vinding, 1 (3): 308 .
} 


\section{Method}

The methodology used in this research is the normative juridical legal research in the form of library research. It is an analysis of secondary data, while the primary data in this study acts only as supporting data. ${ }^{9}$ Secondary data consist of various literature and journals that discuss the Living Law, legal positivism, and transformativeparticipatory legal research methods and primary data, mainly taken by interviews with scholars regarding their expertise in this particular subject. Both data are used in conjunction, but in a technical sense, the secondary data is mainly used as the primary source of the analysis, and in this context, it is used to exemplify and carve out a better understanding of the secondary data and its interpretation. Besides, this research used non-legal materials in the form of interview records related to the subject. The results of this study are descriptive, analytical and prescriptive method. Descriptive-analytical is research conducted descriptively, limited to the effort to reveal a problem and situation as it is, so that it is only explaining or describing an event or fact in detail systematically, and thoroughly while prescriptive is the solution to the legal issues submitted and etymologically means what it should be. ${ }^{10}$

\section{Analysis and Result}

\subsection{A Critique of Legal Positivism}

As a basis for legal positivism, pure legal science gives birth to several premises and postulates that characterize the legal positivism school, namely:11

a. The law is only an order of the authorities and or made by the competent authority;

b. There is no absolute relationship between law, morals, and ethics;

c. Analysis of legal conceptions is distinguished from historical and anthropological investigations;

d. The legal system must be a logical, permanent, and closed system based on logic, without considering social, political, moral or ethical aspects;

e. Law must be seen solely in its formal form, and thus must be separated from its material forms; and

f. The content of the law or legal material is acknowledged to exist, but it is not a material for legal science because it can damage the scientific truth of the law.

In legal positivism, the law is only a rule that governs people's lives in a concrete manner that is empirical and does not include religious norms, ethical norms (moral), and norms of decency. ${ }^{12}$ Legal positivism also tends to ignore the legal substance and is limited to provisions that have been prepared by the state or authorized institution, contained in a set of rules or laws. The method of positivism model analysis has reduced complex legal issues, to problems summarized in articles in the statutory

9 Soemitro, R.H. (1994). Legal Research Method and Jurimetry. Jakarta: Ghalia Indonesia, p. 5.

10 Kurnia, T.S. et. al. (2013). Legal Education, Legal Studies and Legal Research in Indonesia: A Reorientation. Yogyakarta: Pustaka Pelajar, p. 129.

11 Rasjidi, L. \& Putra, I.B.W. (2003). Law as a System. Bandung: Remaja Rosdakarya, p. 81.

12 Rasjidi, L. \& Sidarta, B.A. (1994). Philosophical Law: School of Thought and its Reflections. Bandung: Remaja Rosdakarya, p. 23. 
law. ${ }^{13}$ The school of legal positivism received rebuttal and criticism from various modern schools such as the Historische Rechtsschule school, Sociological Jurisprudence, Pragmatic Legal Realism, Freierechtslehre, even the most advanced is the flow of critical law (Critical Legal Studies). ${ }^{14}$ The following are some criticisms on legal positivism are as follows:

a. School of Historische Rechtsschule:

Friedrich Carl von Savigny states that law is not only issued by the authorities in the form of laws, but the law is the soul of the nation (volkgeist), and its substance is a rule comprised of people's living habits.

b. School of Sociological Jurisprudence:

Ehrlich states there must be a separation between statutory law and the living law in society. Statutory law can be effectively applied if it contains is in harmony with the laws that lives in society. ${ }^{15}$

c. School of Pragmatic Legal Realism:

Oliver Wendell Holmes states "... the life of the law has not been logic. It has been an experience". Adherents of Legal Realism are of the view that law is not what is in the law but what is applicable in practice.

d. School of Freierechtslehre:

Legal logic and "conception of jurisprudence" are inadequate to produce practical decisions. According to this school, the judge is not only often forced to go beyond the law but must also surpass it. ${ }^{16}$

e. School of Critical Legal Realism:

Critical Legal Studies offers a solution so that legal review can be carried out without being trapped by the thought of legal positivism, namely by eliminating the separation between legal doctrine and empirical social theory. Proponents of Critical Legal Studies believe that legal doctrines that continue to expect the separation between legal thinking and ideology and political philosophy will only end up as a troubled apology to society. ${ }^{17}$

Mochtar Kusumaatmadja states that in Indonesia, the law is the main instrument of regulation and community renewal by means of legal reforms, especially legislation. ${ }^{18}$ According to him, law as a social principle that cannot be separated from the values that were to be applied in a society. However, the existing legislation (statutory law) cannot accommodate the values or the living law in the community. As an example, in 2015 there was a dispute between the customary indigenous people of the Pelalawan Regency with the corporate entity known as PT Serikat Putra. The dispute arose from

\footnotetext{
13 Dimyati, K. (2004). Theorization of Law, Study of the Development of Legal Thoughts in Indonesia 1945 - 1990. Yogyakarta: Genta Publishing, p. 72.

14 Nuraeny, H. (2011). Criminal Act of Human Trafficking: Criminal Law Policies and its Preventions. Jakarta: Sinar Grafika, p. 10.

15 Darmodiharjo, D. \& Sidharta. (2006). Principles of Legal Philosophy: What and How is Indonesian Legal Philosophy. Jakarta: PT Gramedia Pustaka Utama, p. 134.

16 Rasjidi, L. \& Rasjidi, I.T. (2004). The basics of philosophy and Theory of Law. Bandung: Citra Aditya Bakti, p. 32.

17 Kasim, I. (1999). Critical Legal Study Movement. Jakarta: Elsam, p. 16.

18 Kusumaatmadja, M. Op.Cit, p. 89.
} 
the issuance of land permits from the local government to the company above the land of the indigenous people of Pelalawan Regency, and which resulted lawsuits from the locals but resulted in the court in favor of the company. It is analyzed that it was attributed to the lack of the Living Law founded in consideration of the legislative, executive, and judiciary power. From the legislative standpoint, Local Regulations are lacking and could be considered non-existent with norms that encompass the Living Law of its customary indigenous people. Due to the disparity between the statutory law and the living law, it also affects the legal considerations made by local officials and court to include the people's values. ${ }^{19}$ From the description of the case, customary law as one of the many manifestations of the Living Law is not heeded, instead statutory law is used as a tool to undermine the values and norms contained in these communities.

\subsection{The Transformative-Participatory Legal Research as a Tool for Harmonization of The Living Law}

In dealing with the disparity between statutory law and the living law which leads to the degradation of the values contained in society, it is necessary to refer to a new paradigm in researching and solving legal problems that continue to develop in their dimensions and complexity. That is one alternative to answer the dilemmas that have been raised. Legal research will be a tool used to solve these juridical problems. Soetandyo Wignosoebroto asserted that legal analysis efforts to find and achieve the right answer and not at all erroneous about the issue, with the results of careful research to answer any existing legal problems. ${ }^{20}$ Therefore, legal research becomes a comprehensive instrument and its implementation can be applied to various layers of the legal world, both academically and practically, in order to create a scientific product that can contribute itself to law itself. Legal research is used to create the following out puts:

Table 1. The use of legal research.

\begin{tabular}{lll}
\hline \multicolumn{2}{c}{ Academic } & \\
\hline 1. Articles & \multicolumn{1}{c}{ Practical } \\
2. Research reports & 1. Legal Memorandum \\
3. Scientific Journals & 2. Legal Opinion \\
4. Undergraduate thesis & 3. Claims/Lawsuits \\
5. Thesis & 4. Indictments \\
6. Dissertation & 5. Memorandum of Defense \\
& & 6. Contract Drafting \\
& & 7. Formal Legal Letters \\
& 8. Legal Audit \\
& 9. Legal Consideration for Court Orders \\
& 10. Academic Manuscripts for Legislation
\end{tabular}

Source: summary by author.

Having understood on legal research and its impact, it is also essential to consider another element of research that is no less important, namely the method. The method in legal analysis becomes a rule of thumb for researchers that provides a method and categorization of legal research that is adjusted to the subject of research or institution

\footnotetext{
${ }^{19}$ Bachtiar, M. \& Fitriani, R. (2017) "Legal Protection for the Rights of Indigenous Peoples in the Pelalawan Regency Related to the Issuance of Land Permits". Media Hukum, 24 (1): 74-78.

${ }^{20}$ Ali, Z. (2011). Legal Research Method. Jakarta: Sinar Grafika, p. 8.
} 
where the results of the investigation will be addressed..$^{21}$ The problem is, in Indonesia there is an understanding of research methods which, although it continues to be developed, tend to pivot on monistic research that gives an image that legal analysis tends to confine the researchers. Sunaryati Hartono spoke that with various kinds of inquires in law, it is difficult to accept the assumption that only one method of legal research is the most suitable and correct. Principally, it could not appear in the form of its purest method but only showing the nature of giving more attention to a specific direction (overheersend), but not limited to that one direction. ${ }^{22}$ That is why the development of the concept of legal research continues to grow and tries to reject perceptions of the nature of legal analysis as restrictive, and it brought about the emergence of the "transformative-participatory" legal research.

Transformative-participatory legal research is a research approach that uses various methods in legal research based on the participatory paradigm and prepares them by using mixed research methods that seek to find alternatives to what is not found in conventional legal investigations. ${ }^{23}$ By harmonizing the framework of thought and functional techniques contained in normative and empirical research, the transformative-participatory legal analysis is expected to become a legal research method that can present comprehensive results on answering the current legal problems. Anthon F. Susanto stated that the type of legal research could be said as a participatory transformative legal research. There are some characteristics of the participatory transformative legal research as follows: 24

a. Nomological-Normative:

Legal analysis remains normative. The legal research will undoubtedly relate to legislation and policies but does not limit itself to the understanding that lies in the formal context but rather to see these norms and their relation to existing values. Law is not limited to the scope of written rules but rather is seen as a rule that has a multi-dimensional inside which contains the dimensions of morality, politics, language, economics, and symbols that can be seen by everyone.

b. Collaborative:

Legal research needs to examine human activities. The research studies social interactions and actions that affect those interactions, to create an increase in community interaction.

c. Critical:

Legal research that explores fundamental issues and essential nature behind a legal problem.

d. Participative:

Legal research is contextualized participation in two dimensions. First, for researchers to position themselves as individuals or as a collective where social and legal realities located. Second, for the community, where the research seeks to

21 Sonata, D.L. (2014). “Normative and Empirical Legal Research Method: A Special Characteristic from the Legal Research Method". Jurnal Fiat Justisia, 8 (1): 23.

${ }^{22}$ Hartono, S. (1994). Legal Research in Indonesia on the End of the 20th Century. Bandung: Alumni, p. 121.

23 Susanto, A.F. Op.Cit, p. 181.

24 Ibid, p. 179-181. 
provide a broad forum for the community to involve themselves and build groups within it.

\section{e. Emancipative:}

Legal research aims to help people and free themselves from the pressures of social, legal, economic, political, and marginalize structures so that each party in the study is given the same position. To achieve this position, all parties in the research need to be involved from the beginning to the end of the study.

f. Transformative:

Legal research, in raising a problem, needs to bring each party to the reality so that an understanding of the posed question to find an answer to the expectations of the parties.

g. Transgressive:

Legal research must not be constrained by studies that are narrow and monodisciplinary, and not fixed by the procedure even though it continues to be used.

The seven characteristics above illustrate the essence of transformative-participatory legal research. From this characteristic framework, it can be said that participatory transformative legal research is a legal research method that although still examining legal norms, does not limit it to a restrictive scope but instead tries to explore and delves in the fundamental values and problems of a legal matter, and no longer places other parties in the research as the object of the study, but try to include the parties in an equal standing so that through this research, a review is created to reflect and accommodate the values held by the community.

As to fully comprehend the vital role of the transformative-participatory legal research on strengthening the convoluted and less effective research and methodology of the legal discipline in Indonesia, it is relevant to refer to the statement on an interview made by Professor Jeane Neltje:

“... that the current (conventional) legal research method are less optimal in answering arising legal issues. While both the normative and empirical legal research in theory aims to have great intentions, in practice both legal research method are less effective in obtaining comprehensive results. Whereas the normative legal research tends to put its focus on its research on the norms and the codified statutory law, the empirical legal research while having relation in its research to society tend to take an 'in and out' approach where the researcher comes in to the field of research and leaves when the necessary data or source has been procured. ... The transformative-participatory legal research method while still taking account on the foundations of the conventional legal research methodology, differs itself with its depth of participation. That in its essence, the transformative-participatory legal research is an 'engagement/involving legal research' ..."

It is evident that transformative-participatory legal research, though was born out of dissatisfaction of legal researchers with normative-dogmatic and quantitative- 
empirical research, does not neglect both legal studies. It is legal research that adopts both normative legal analysis and empirical and multi-dimensional empirical legal research, but it must be understood that transformative-participatory legal research is not socio-legal research. Socio-legal research although focuses its attention on the real law (law in action), still pays attention to the law in the formal form (law in books) and therefore has an interdisciplinary nature. ${ }^{25}$ At first glance it can be seen that socio-legal research has a significant similarity to participatory transformative research, but are the two research concepts the same? No, because participatory transformative legal research has two variables that are not or rarely considered by socio-legal research on empowerment and participation. Empowerment is defined as strengthening the power of society from factors that arise from the community itself individually and factors from social structures so that there is growth in the independence of the community. Whereas participation is organized as an active process whereby the community contributes voluntarily and sensitizes the community in responding to the law to achieve self-development, community groups and its environment. ${ }^{26}$

All of these things culminate into an ideal legal research method to become the "bridge" of the living law into the legal structure in Indonesia. In line with above description the research tries to formulate the usage and impacts of implementing the transformative-participatory legal research into the state order of the government as to fully promote the existence of the living law. There are some branches of the transformative-participatory research method as follows:

a. Executory:

Through transformative-participatory research methods, the state apparatus and state officials can deliver legal products that accommodate the people so as to reduce injustice and marginalization to the community, such as the preparation of indictments, court decisions, etc.

b. Legislation:

For legislation, the transformative-participatory research method could bring effecst such as: ${ }^{27}$

1) Pre-Legislation:

Through the participatory transformative legal research method, the Living law can be included in the research and be the focal point of the study with an objective to achieve academic manuscripts to design the laws and regulations with the living law in mind, such as implementing the participatory transformative legal research method through the enactment of community aspirations networks (jaringan aspirasi masyarakat), which through the community's participation as subjects in the research, builds a statutory law

\footnotetext{
${ }^{25}$ Hakim, M.H. (2016). "Shifting Legal Research Orientation: From Doctrinal to Socio-Legal”. Jurnal Hukum dan Pemikiran, 16 (1): 106.

26 Susanto, A.F. Op.Cit, p. 87-89.

27 Aziz, N.M. (2012). "Urgency of Research and Legal Review in the Formation of Legislation". Jurnal Rechts Vinding, 1 (1): 27-28.
} 
that is cohesive with the ideals of the community in which the law would be enacted upon. 28

2) Post-Legislation:

With the transformative-participatory legal research, the socialization and enactment of the regulations can be evaluated, and with it, the effectiveness of the regulation and the norms of The Living Law could be sharpened. In this period, the transformative-participatory research method does not inherently cause a direct influence for harmonization of The Living Law but serves as instrument for re-evaluation for the current positive law and could be used as tool for revision.

c. Adjudication:

In passing a decision/order, the court and judge will examine and solve legal problems not only using statutory law, but through transformative-participatory research can promote or protect the living law in society. As revealed in Article 10 of Law No. 48 of 2009 concerning Judicial Power, "The court is prohibited from refusing to examine, judge, and decide on a case filed under the pretext that the law does not exist or is unclear, but it is obligatory to examine and judge it."

\section{Conclusion}

By fulfilling particular characteristics and implementation, a legal research could serve as a tool of harmonization. It empowers the people and gives them standing in legal investigations. Communities and society as a whole are not the objects of observation but rather subjects that participate in this research. It harmoniously triangulates the norms and experience of legal researchers, the action of the society, and reflects on the legal problems. It urges both scholars and practitioners of law research and creates scientific and legal products that do not enclose heavily on one side of the legal spectrum but rather achieve equilibrium. Through the transformative-participatory legal research, legal researchers would still accommodate the essence of legal analysis founded in conventional methods, but it will not be confined by those methods. Judicial powers will search and unearth norms within the society to accommodate the existing statutory law, the executive authorities will discreetly employ the people's will side by side with the will of the statutory law, and the legislative powers will integrate the values founded in communities. All in all, those powers will attain the goal of harmonizing existing and coming regulations in Indonesia.

\section{References}

\section{Books:}

Ali, Z. (2011). Legal Research Method. Jakarta: Sinar Grafika.

Darmodiharjo, D. \& Sidharta. (2006). Principles of Legal Philosophy: What and How is the Indonesian Legal Philosophy. Jakarta: PT Gramedia Pustaka Utama.

28 Fatkhurohman \& Sjuhad, M. (2018). “The Influence of Implementing Community Aspiration Network in the Formation of Participatory Local Regulations". Media Hukum, 25 (2): 193-197. 
Dimyati, K. (2004). Theorization of Law, Study of the Development of Legal Thoughts in Indonesia 1945 - 1990. Yogyakarta: Genta Publishing.

Hartono, S. (1994). Legal Research in Indonesia on the End of the 20th Century. Bandung: Alumni.

Kasim, I. (1999). Critical Legal Study Movement. Jakarta: Elsam.

Kurnia, T.S. et. al. (2013). Legal Education, Legal Studies and Legal Research in Indonesia: A Reorientation. Yogyakarta: Pustaka Pelajar.

Kusumaatmadja, M. (2000). Legal Concepts in National Development. Bandung: Penerbit Alumni.

Nuraeny, H. (2011). Criminal Act of Human Trafficking: Criminal Law Policies and its Preventions. Jakarta: Sinar Grafika.

Rasjidi, L. \& Bernard. A.S. (1994). Philosophical Law: School of Thought and its Reflections. Bandung: Remaja Rosdakarya. . \& Ida Bagus W.P. (2003). Law as a System. Bandung: Remaja Rosdakarya. \& Ira T.R. (2004). The Basics of Philosophy and Theory of Law. Bandung: Citra Aditya Bakti.

Soemitro, R.H. (1994). Legal Research Method and Jurimetrics. Jakarta: Ghalia Indonesia.

Susanto, A.F. (2015). Transformative-Participatory Legal Research. Malang: Setara Press.

\section{Journals Articles:}

Aziz, N. M. (2012). "Urgency of Research and Legal Review in the Formation of Legislation". Jurnal Rechts Vinding, 1 (1).

Bachtiar, M. \& Riska F. (2017). “Legal Protection for the Rights of Indigenous Peoples in the Pelalawan Regency Related to the Issuance of Land Permits". Jurnal Media Hukum, 24 (1).

Dainow, J. (1966). "The Civil Law and The Common Law: Some Points of Comparison". The Americal Journal of Comparative Law, 15 (3).

Fatkhurohman \& Sjuhad, M. (2018). “The Influence of Implementing Community Aspiration Network in the Formation of Participatory Local Regulations". Jurnal Media Hukum, 25 (2).

Hadi, S. (2017). "Positive Law and The Living Law (Its Existence and Enforceability in Society)". DiH Jurnal Ilmu Hukum, 13 (26).

Hakim, M.H. (2016). "Shifting Legal Research Orientation: From Doctrinal to SocioLegal". Jurnal Hukum dan Pemikiran, 16 (1).

Hoesein, Z.A. (2012). "Legal Formation in the Perspective of the Legal Reform". Jurnal Rechts Vinding, 1 (3).

Prabandani, H.W. (2011). "Local Wisdom-Based Legal Development". Jurnal Perencanaan Pembangunan, 17 (1). 
Sonata, D.L. (2014). “Normative and Empirical Legal Research Method: A Special Characteristic from the Legal Research Method". Jurnal Fiat Justisia, 8 (1).

Susanto, A. F. \& Gialdah T. B. (2016). “Transformative Participatory Legal Research: An Idea and Early Concept". Jurnal Litigasi, 17 (2).

\section{Regulations:}

Constitution of the Republic of Indonesia of 1945.

Law Number 48 of 2009 concerning The Judiciary Power.

Law Number 5 of 1960 concerning Basic Agrarian Principles.

Law Number 1 of 1974 concerning Marriage. 